\title{
IDENTIFICATION OF PROBLEMS OF FINANCIAL AUTONOMY IN LITHUANIAN RURAL MUNICIPALITIES
}

Laima SKAURONE், Institute for Bioeconomy Research, Vytautas Magnus University, K. Donelaičio g. 58, LT-44248 Kaunas, Lithuania, laima.skaurone@ vdu.lt (corresponding author)

Deimena MONTVYDAITÉ, Vytautas Magnus University, K. Donelaičio g. 58, LT-44248 Kaunas, Lithuania, deimena.montvydaite@vdu.lt

The scientific problem addressed by the article is the lack of the ways for identification and solution of the issues of financial autonomy in rural municipalities. The aim of the article is to identify the problem areas of financial autonomy in Lithuanian rural municipalities. The problem areas of financial autonomy in rural municipalities have been identified under the methods of scientific literature analysis, document analysis, and-statistical data analysis, and comparative analysis. The problematics of definition of the phenomenon of financial autonomy of rural municipalities has been noticed; problem areas of expenditure, revenue, financial transfers and borrowing in the municipalities have been identified. The empirical study of the data on 50 Lithuanian rural municipalities reflecting their respective financial autonomy in the period 2014-2018 (municipality revenue structure, revenue per capita, the dynamics of the share of the personal income tax (PIT)) revealed that the major share of the revenues of rural municipalities is collected by means of the PIT. There are four donor municipalities in Lithuania - Vilnius city, Kaunas city, Klaipeda city and Neringa municipalities - with their PITs used to support rural municipalities. The central authorities of Lithuania apply inter-budgetary reallocation of funds in order to introduce the financial equalization measures to adjust for the unequal allocation of potential financial resources between the municipalities with the ultimate objective of eliminating the territorial, social and economic disparities between the municipalities. However, the revenue and expenditure remain unequalized between the municipalities.

Keywords: financial autonomy, fiscal decentralization, problems of financial autonomy.

\section{INTRODUCTION}

The phenomenon of financial autonomy of municipalities could, from the perspective of scientific literature, be referred to as a paradigm still requiring considerable expertise to be built and scientific knowledge to be acquired. According to foreign (Friedrich et al., 2003, 2010; Oulasvirta, Turala, 2005, 2009; Mosteanu, Lãcãtu, 2008; Beer-Toth, 2009; Cigu, 2013; Scutariu, Scutariu, 2015; Psycharis et al., 2016; Kopanska, 2017 and others) and Lithuanian (Astrauskas, 2002, 2007; Astrauskas, Striškaitè 2003; Bivainis, Butkevičius, 2003; Davulis, 2004, 2006, 2007; Raipa, Backūnaitė, 2004; Civinskas, Tolvaišis, 2006; Mačiulytė, Ragauskas, 2007; Davulis et al., 2013; Slavinskaite, 2017 and others) authors, financial autonomy of municipalities provides greater manoeuvrability to the country's financial system and allows for addressing the economic and social issues of the authorities on the subnational level. With more autonomy and authority in formation of local budgets and in decision-making in relation to management of financial resources, municipalities can implement the regional and municipal economic and social development plans properly. Nonetheless, the findings of the scientific and applied research works have demonstrated financial dependence of the local authorities on the central authorities, which signals that the possibilities of the municipalities to allocate the funds at own discretion and form the regional policy are negligible. The phenomenon of financial autonomy of municipalities has been declared extensively in the national legislative documents, analysed fairly comprehensively by the representatives of different areas of social sciences who define the issues, put forward the solutions, but, in practice, financial autonomy is not being assured properly, and the economic theoretical foundation of the phenomenon continues to be debatable.

It should be noted that the issues of improvement of financial autonomy in Lithuania, identified by the Lithuanian researchers more than two decades ago and analysed ever since, have either remained unchanged or poorly resolved until present. It is also important to consider that both foreign and Lithuanian researchers identify the issues with the general focus on improvement of financial autonomy of all the municipalities, while problem areas of financial autonomy in rural municipalities have received little individual consideration. Hence, the topic urges for building an in-depth scientific understanding, which would result in the capacity to not only identify, but also address the issues of improvement of financial autonomy in rural municipalities. This substantiates the relevance of the scientific problem not only in the Lithuanian, but also in other countries' contexts. Consequently, the present article analyses the main scientific problem: the lack of the ways for identification and solution of the issues of financial autonomy in rural municipalities. Research object: the issues of financial autonomy in rural municipalities. Research aim: to identify the problem areas of financial autonomy in Lithuanian rural municipalities following the analysis of theoretical concepts of the financial autonomy. Research methods: scientific literature

Copyright (C) 2019 The Authors. Published by Vytautas Magnus University. This is an open-access article distributed under the terms of the Creative Commons Attribution License (CC-BY 4.0), which permits unrestricted use, distribution, and reproduction in any medium, provided the original author and source are credited. 
analysis, document analysis (Lithuanian law documents), statistical data analysis (Lithuanian rural municipalities data: municipality revenue structure, revenue per capita, the dynamics of the share of the PIT), comparative analysis.

\section{THE PROBLEMATICS OF DEFINITION OF THE FINANCIAL AUTONOMY PHENOMENON IN MUNICIPALITIES}

The scientific literature analysis has revealed that the theoretical grounds behind the financial autonomy phenomenon in municipalities lie in the concept of fiscal decentralization. Tiebout (1956), the founding father of the concept of fiscal decentralization, built the foundation of the concept of fiscal decentralization by developing the theory of local expenditures and demonstrated its effect on the country's wellbeing. Later, Musgrave (1959) identified the theory of fiscal federalism as an individual section of economics, and Oates (1999) continued developing the idea. Essentially, in the theory of fiscal federalism, Tiebout (1956) and Musgrave (1959) were the first ones to identify two levels of public finance management, namely, central and local. A detailed analysis of the concept of decentralization was performed and published only in the beginning of the 80 s of the last century. Foreign researchers predominantly focused on exploration of the appropriate methods for implementation of fiscal decentralization, optimal allocation of responsibility and financial resources between different levels of governance, and identification of the areas subject to decentralization.

In the research studies by the Lithuanian authors (Raipa, Backūnaite, 2004; Davulis, 2006, 2007; Astrauskas, 2007; Buškevičiūtè, 2008; Baltušnikienè, 2004, 2009; Slavinskaitè, 2017), fiscal decentralization is analysed as a mechanism of control of the government expenditure. Fiscal decentralization is adapted to the Lithuanian context, including emphasis on improvement of the efficiency of public economy sector by decentralization of its respective functions. There is obviously a great variety of definitions of fiscal decentralization. The phenomenon has been analysed by a number of researchers (Mclure, Martinez-Vazquez, 2000; Boex, 2001; Lazdynas, 2001; Bivainis, Butkevičius, 2003; Raipa, Backūnaitė, 2004; Davulis, 2006, 2007; Astrauskas, 2007; Buškevičiūtė, 2008; Baltušnikienè, 2009; Aristovnik, 2012; Slavinskaitè, 2017). Analysis of the available definitions of fiscal decentralization proposed by the researchers suggests that different aspects of financial responsibility prevail in the definitions, with the focus on improvement of financial autonomy through allocation of the financial authority and resources between the central and local government entities. Hence, the general perspective towards the content of the theory of fiscal decentralization suggests the following 3 interacting components of the phenomenon: local government expenditure, revenue, and budget autonomy. According to the researchers' stipulations, the following components of the variables of financial autonomy of municipalities are possible: allocation of revenue, expenditure, budget management autonomy, transparent intergovernmental fiscal transfers, clear borrowing mechanism, and provision of sustainable responsibility for public services and transfer of the related expenditure. The scientific literature analysis has allowed for identification of the levels of the financial autonomy variables: first, expenditure autonomy of a local government is defined as the local government expenditure on public services and goods on the basis of the local community needs; second, revenue autonomy of a local government means that the local government has the respective institutions and responsibility in decisionmaking in relation to financial resources; third, budget autonomy of a local government shows the degree of revenue management by the local government, which is associated with the expenditure level (Beer-Toth, 2009; Slavinskaite, 2017).

Hence, although the concept of local financial autonomy is identified as the main concept in the scientific literature, little contribution has been made to explanation of its meaning. A decentralized governance process still lacks an established definition of local autonomy, and there is still no clear consensus as to which elements may comprise it or how it should be assessed (BeerToth, 2009). Analysis of the scientific literature has shown that the issues of financial autonomy in a public sector from the economic perspective have been analysed by a few experts, theorists, and practitioners. The concept of financial autonomy does not offer a scope or a universally recognized definition. Oulasvirta, Turala $(2005,2009)$ define the essence of financial autonomy as the autonomy of revenue and expenditure. Beer-Toth (2009) refers to local financial autonomy as a combination of expenditure autonomy, revenue autonomy, and budget autonomy. Jemna et al. (2013) explain financial autonomy in a municipality as a freedom of establishing local taxes, receiving revenues via the assigned resources, allocating own financial resources and material resources, establishing and approving own annual budget without any disturbances from the outside. According to Cigu (2014), from the financial perspective, autonomy may be defined by combining the three components: local expenditure autonomy, local revenue autonomy, and local budget autonomy. Scutariu, Scutariu (2015) believe that local financial autonomy may be considered as the capacity of local authorities to manage the financial resources that are used to satisfy the interests of the local society. Lithuanian researchers, for example, Rudyte et al. (2018), tend to associate fiscal autonomy, primarily, with the authorities in the tax area and allocation of the responsibility for provision of public goods and services. According to the authors, establishment of tax rates and base is the main prerequisite of financial autonomy.

In general, it could be claimed that the phenomenon and concept as well as content of financial autonomy of municipalities have not been defined clearly from the economic perspective. The scientific literature analysis performed has demonstrated the problematics of definition of the concept of financial autonomy of municipalities. This proves that financial autonomy in municipalities is a relevant object of research.

\section{THE PROBLEMATICS OF FINANCIAL AUTONOMY IN MUNICIPALITIES: LEGAL, ADMINISTRATIVE, FINANCIAL ASPECTS OF ASSESSMENT}

Legal regulation of fiscal decentralization is established in the Constitution of the Republic of Lithuania (1992), European Charter of Local Self-Government (1999), Laws of Local Self-Government (1994), Budget Structure (1990), 
and other legal acts regulating receipt of budget revenues and programme funding. The Lithuanian researchers emphasize that fiscal autonomy in municipalities is established more in the legal acts, while, in practice, it is not ensured sufficiently. The current Law of Local Self-Government of Lithuania (1994) provides strict definitions of the self-government functions, which, according to the discretion in the decision-making, are classified into: independent, assigned (of limited independence), state (delegated by the State to municipalities), and contractual. From the perspective of financial analysis, the three first functions are the most important. In terms of the legal and administrative level of financial autonomy in municipalities, local self-government bodies should have: the authority to collect taxes and receive financial resources from the central government necessary for implementation of the functions delegated; the authority to use the financial resources without excessive prior control of higher authorities; the authority to make decisions regarding own operations without involvement of the central government administration (planning authorities and ministries); sufficient, competitive staff and the authority to employ and to dismiss members of staff; obtain the technical and material facilities as may be required and consultation assistance from the central authority bodies (Mačiulyte, Ragauskas, 2007).

According to Civinskas and Tolvaišis (2006), implementation of the local self-government principles is inseparable from decentralization of the finance domain. Fiscal decentralization creates the conditions for rapid social and economic development, but it may also cause certain financial difficulties to some local self-government authorities. For the local government and private organizations to effectively implement the decentralized functions, they must have the revenue of a certain level, whether increased locally or transferred from the central government, and the authority to make decisions regarding the expenditure. According to Mačiulytè, Ragauskas (2007) the principle of economic autonomy is one of the key securities of local self-government. Hence, the financial resources necessary for implementation of the competences delegated to the local self-government authorities may be formed by transfer of the funds which used to be allocated to implementation of the functions or by allowing the municipalities to directly collect certain taxes themselves. Friedrich et al. (2004) provide the classification of potential taxes, proposing to assign management of certain taxes to a lower-tier authority, i.e. a municipality (Table 1).

Table 1. Fiscal autonomy in local governments.

\begin{tabular}{|l|l|}
\hline Taxes & Financial autonomy in tax administration and management \\
\hline Own taxes & Base and rate under local control. \\
\hline Sherlapping taxes & Nation-wide tax base but rates under local control. \\
\hline $\begin{array}{l}\text { General purpose } \\
\text { grant }\end{array}$ & $\begin{array}{l}\text { Nation-wide base and rates, but with a fixed portion of the tax revenues (on a tax-by-tax basis or on the basis } \\
\text { revenues accruing within each jurisdiction (also so-called the derivation principle) or (2) other criteria, } \\
\text { typically population, expenditure needs, and/or tax capacity. } \\
\text { former is free to determine how the grants should be spent; the amounts received by individual authorities } \\
\text { may depend on their tax efforts. }\end{array}$ \\
\hline Specific grants & $\begin{array}{l}\text { The absolute sum of grant may be determined by central government or it may be open-ended (i.e. dependent } \\
\text { on the expenditure levels decided by lower levels of government), but in either case central government } \\
\text { specifies the expenditure programmes for which the funds should be spent. }\end{array}$ \\
\hline
\end{tabular}

Resource: Friedrich, Kaltschuetz et al. 2004.

Santos (2016), Davulis (2007), Wei (2014) note that the degree of financial autonomy in a municipality is characterised by the relation between the tax revenue and the revenue used by the municipality to fund the functions performed independently with the subsidies from the state budget for implementation of the functions delegated by the State. High level of the subsidies in the total revenue structures would mean relatively lower financial autonomy in the municipality. Based on the traditional first-generation fiscal federalism theory (Oates, 1999), it is claimed that two budget functions need to be performed in a centralized manner, namely, the macro-economic stabilization and redistribution. It is best to perform the third budget function, namely, allocation, on the local level. Switzerland is probably the only country which had made it this far in distancing the revenue distribution function from the centralized governance system, as the health care, education functions and creation of wellbeing are implemented on the local governance, i.e. canton, level, with individual cantons holding their priorities in collection of the personal income tax. This example clearly shows that there is the alternative of assigning the revenue redistribution function to the local levels (Fiechter, 2010; Slavinskaite, 2017).).

Nonetheless, analysis of scientific sources shows the key issues related to fiscal decentralization, which also determine the issues of improvement of financial autonomy. First, the process of fiscal decentralization is controversial and may not always be viewed favourably. The second obstacle is the inadequate competence of the local staff. The third issue lies in that, if the criteria of rationality of the local budget model, locals are to suffer from the financial failures. Another issue could be noted, namely, that the local finance system still shows the aspiration to seek the highest possible expenditure and revenue instead of reducing the scope of the public sector services provided or even abandoning some of them by passing them to private structures. The fifth issue is that the process of fiscal decentralization may be slow due to the irrational decisions by the central authority. For examples, in most countries, the responsibility of the local authorities for the expenditure is laid down in the laws, resolutions, while revenues from taxes or other decentralized activity are limited (in Lithuania as well). Hence, in this case, the vertical balance is disrupted. For subjective reasons, other obstacles may emerge, for example, the local governance bodies which follow the instructions by the central authorities are usually remunerated by allocation of a larger amount of financial resources compared to the local governance bodies which show local initiative and promote proactive position of the local community. Horizontal balance may be disrupted as well, as poorer regions do not have enough capacities to provide the public goods and services, while the fiscal transfers allocated by the central authorities are too small. Another issue which has become 
evident is the occasional situation, when, after the fiscal decentralization has been implemented, the central authorities exercise comprehensive control over the local authorities and limit its powers by adjusting the scope and structure of the public services to the local needs (Zafra-Gómez et al., 2014; Buškevičiūtè, 2008). With the focus on financial autonomy of rural municipalities, similar issues become evident. Primarily, the scientific literature analysis has shown that all the researchers usually analyse the issues of financial autonomy of individual countries and all the municipalities, with very little attention to the problematics of financial autonomy in rural municipalities. Considering the scarce availability of specific research results, it could be assumed that the issues emphasized by the researchers are also characteristic of the financial autonomy of rural municipalities.

In summary, the scientific literature analysis results have allowed for identifying the causes related to autonomy of activity by municipalities which determine the issues of financial autonomy in municipalities. The issues have been identified based on the obstacles, shortcomings in promotion, development of financial autonomy in municipalities referred to in the works of various researchers. The issues of the case of Lithuania are presented by means of the components of financial autonomy (municipality expenditure, revenue, financial transfers, and possibilities for borrowing) identified in the context of fiscal decentralization (Fig. 1).

\section{LACK OF AUTONOMY IN OPERATIONS OF THE MUNICIPALITIES: THE REASONS}

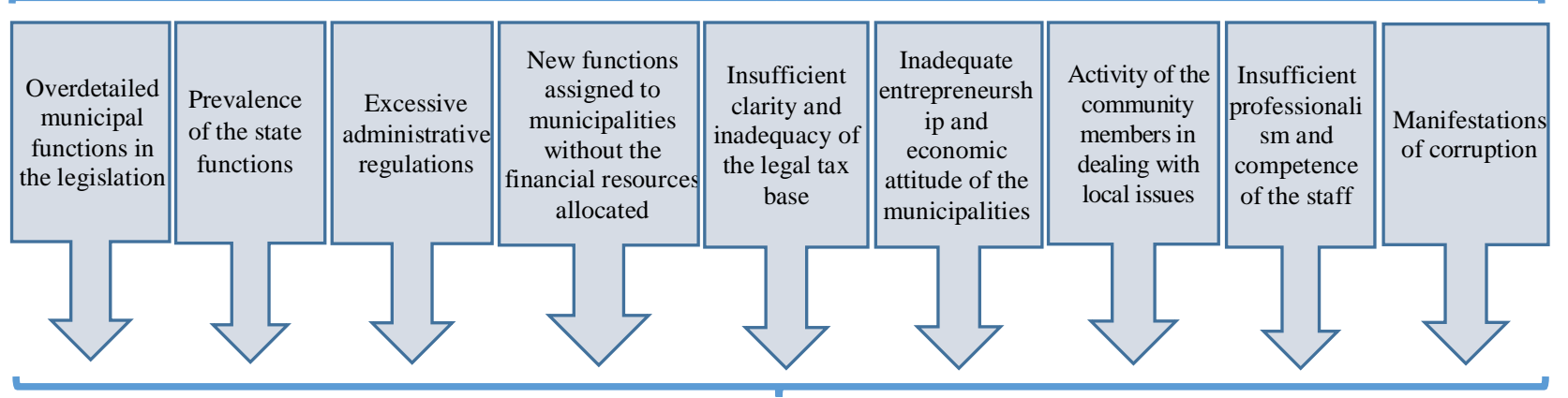

IMPLICATIONS OF FINANCIAL AUTONOMY OF MUNICIPALITIES

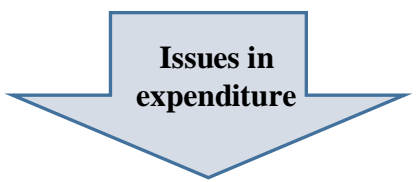

Comparison of the municipal expenditure to the national expenditure and GDP does not reflect the specifics of formation of the municipal expenditure: it is not clear whether the revenues intended to fund the functions of certain municipalities have been taken from the local taxes or state budget as a targeted grant

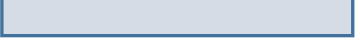

The Law of Lithuania on Methodology for Determination of the Municipal Budget Revenues establishes considerable limitations regarding autonomy of the municipalities in allocating the appropriations to the

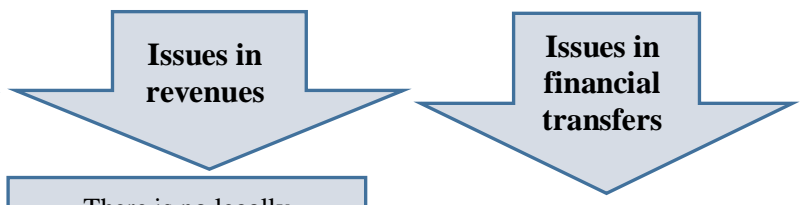

There is no legally established clear institute for local taxes. Local taxes account for a small share in the municipal revenues, not encouraging the municipalities to collect and manage such taxes

Inadequate activeness of the municipalities in managing certain taxes assigned to them

Taxes assigned to the municipalities do not perform the fiscal (accumulation) function

Decisions by the state authorities weaken the institute of tax revenues of municipalities

Municipalities are not provided with the authority to determine the

Grants prevail in the budget revenues
Differences in the PIT and expenditure structures between the municipalities are levelled out at the expense of donor municipalities, which does not promote the rural municipalities to explore and perform with the

The legally established funding of the state functions and student's 'basket' using targeted grants weakens autonomy of municipalities, as the purpose of use of the funds is limited by the legislation

Large scope of the targeted grants in the municipal budgets

$$
\text { power }
$$

Inadequate allocation of the sources of budget revenues for each governance tier

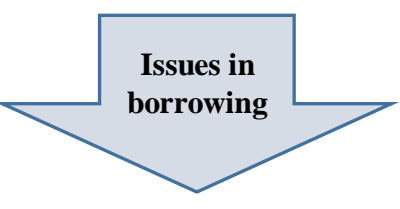

No legal-administrative mechanism enabling the municipalities to receive

loans of the size and duration which would be adequate for them to repay the loans within the established time limits

Lack of the borrowing limits for the municipalities does not enable them to fund current expenses and investment projects properly and on time.

The government promotes continued indebtedness of municipalities, thereby violating the principles of financial proportionality and parallel financing

Source: Compiled by authors based on analysis of scientific sources.

Figure 1. Tree of problems of financial autonomy in Lithuanian rural municipalities. 
In general, from the legal, administrative, financial aspects of financial autonomy of municipalities, it could be claimed that legal regulation of fiscal decentralization has been established in the national and international legal acts governing receipt of budget revenues and programme funding. The scientific literature analysis has shown that the financial, economic autonomy is key principle of autonomy of municipalities. As a result of generalization of the information, the problematics of definition of the phenomenon of financial autonomy of municipalities, problem areas in municipalities associated with disturbances in expenditure, revenue, financial transfers, and borrowing, have been identified. To assess the situation and level of the issue of financial autonomy in Lithuania's rural municipalities, comprehensive complex research studies are required. The following chapter presents a fragment of the empirical studies on financial autonomy in rural municipalities conducted by the authors of the article.

\section{FINANCIAL AUTONOMY OF LITHUANIA'S RURAL MUNICIPALITIES: SITUATION ANALYSIS}

At present, the territory of the Republic of Lithuania consists of 10 counties and 60 municipalities, of which 49 are district, and 11 - city municipalities. The administrative units of the territory of the Republic of Lithuania consist of the residential areas which are classified into urban and rural ones. Cities are attributed to the urban residential areas, while towns, villages and single-homestead settlements are attributed to the rural residential areas. At present, the average population in the Lithuanian municipalities is 55965 (according to the year 2017 data by the Statistics Lithuania).

The analysis of scientific sources has shown that the municipalities of the Republic of Lithuania are classified in line with the three-tier classification applied in the methodology of the Organization for Economic Cooperation and Development (OECD), i.e. into rural, semi-rural, and urban regions (Vidickienė, Melnikienè, 2008). Quantitative limits used in the OECD methodology are proposed to apply to attribution of the municipalities to the rural ones in the present study, namely, rural municipalities are considered to be the municipalities, where more than $50 \%$ of the residents reside in the rural type residential areas, while the municipalities where 15 to $50 \%$ of the residents live in the rural residential areas are classified as semi-rural. Hence, in line with the three-tier classification under the OECD methodology, 50 rural/district municipalities of the Republic of Lithuania have been identified. The data reflecting financial autonomy of the rural municipalities for the period 2014-2018 have been analysed. The article presents the revenue structure of the municipalities (year 2017), revenues per capita by municipalities, variation in the share of the PIT (\%) (2014-2018).

Current statistical data show that the areas of the Lithuanian municipalities are large, exceeding the average municipality area (48.6 sq.km) in the EU-28 countries by more than 22 times. The EU countries do not have the self-government constructs which would be in charge of the vast territories with 50-60 thousand or more residents (except for Denmark, United Kingdom, and Lithuania) and the major cities, but would have little powers to make autonomous decisions, and their activity would be limited by the local budget that does not match the basic needs. This means that Lithuania violates the European Charter of Local Self-Governance, although it has made the commitment to follow the Charter.

The central authorities of Lithuania declare that, in planning and implementation of the national regional policy measures, the Government and the Ministry of Interior seek sustainable development of all the country's territories by investment into small and medium towns, in particular, in more distant regions, efforts to secure quality, clean and safe living environment which is necessary in addressing the demographic issues, maintaining qualified labour force (as a guarantee of development possibilities for the basic sectors of economy in the future), and making use of the potential of the urban attraction centres for improvement of the investment environment, creation of jobs (by adapting the existing or creating new urban public spaces), improving the mobility potential for the residents of the cities and surrounding areas. The policy of municipalities is primarily related to financial resources. Personal income and property (land, immovable property) taxes are the main source of revenue for the municipalities. Figure 2 presents the revenue structure of rural municipalities in 2017.

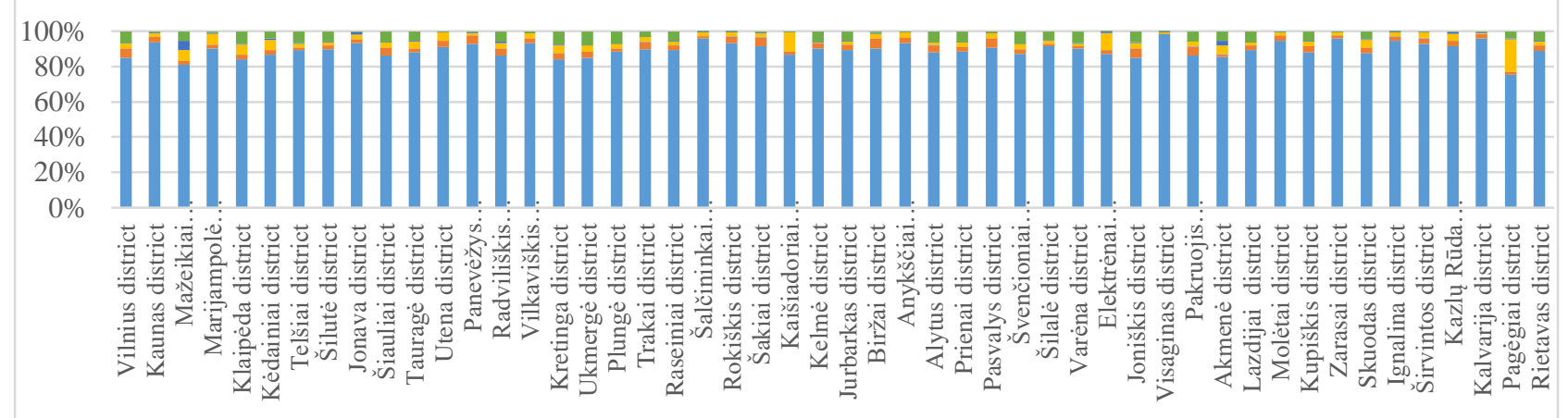

- Personal income tax $\square$ Land tax $\square$ Inherited property tax $\square$ Immovable property tax $\square$ Environmental pollution tax $\quad$ Other levies Source: Compiled by authors based on data from the Department of Statistics of the Republic of Lithuania (2017).

Figure 2. Structure of income of rural municipalities in 2017.

Figure 2 suggests that the major share of the revenues of rural municipalities is collected by means of the personal income tax (hereinafter - the PIT). Considering the reducing working-age population in the regions, the revenues generated by the PIT are reducing in the municipalities as well. Nonetheless, there are four donor municipalities in 
Lithuania (Vilnius city, Kaunas city, Klaipeda city and Neringa municipalities), with their PITs used to support rural municipalities.

Analysis of the share of the PIT $(\%)$ redistributed in the rural municipalities in the total revenue structure in 2014 2018 shows that the percentage share of the PIT has been consistently growing since 2014 (Fig. 3).

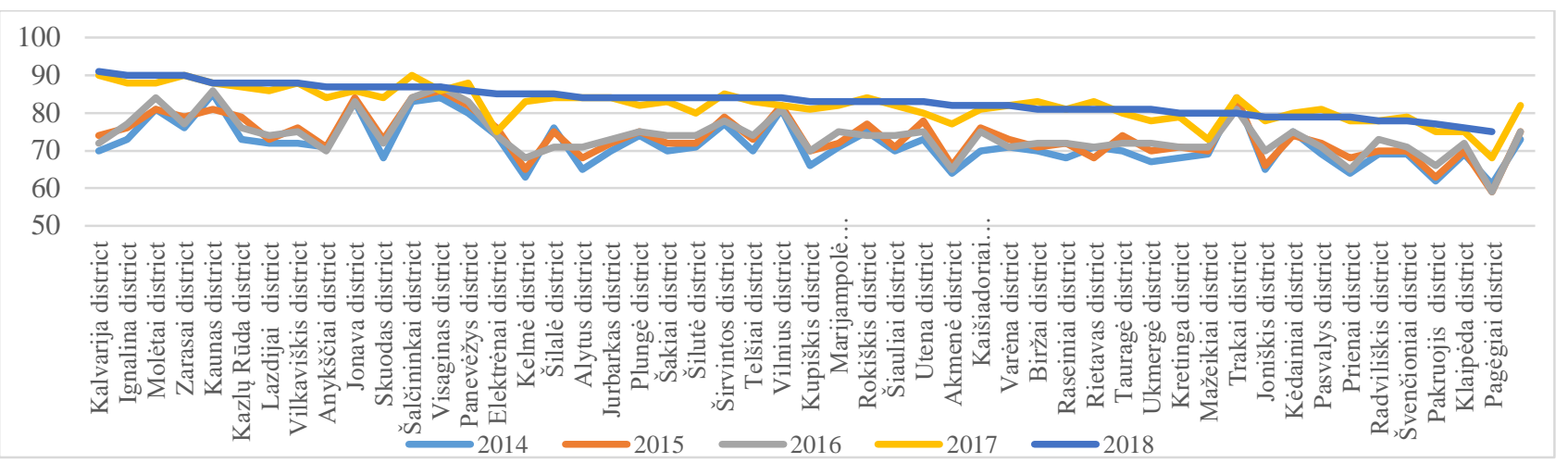

Source: Compiled by authors based on data from the Ministry of Finance of the Republic of Lithuania.

Figure 3. Share of rural municipalities redistributed Personal Income Tax in percentage of total income structure, 2014-2018.

For example, in Kalvarija, Kelmè, Kreting, and Zarasai district municipalities, the PIT share (\%) in the total revenue structure increased by one quarter from the year 2014 to 2018. In 2014, the PIT share of Kretinga municipality was $68 \%$, while in 2018, the share was $80 \%$, which meant increase by as many as 28 percentage points; in Zarasai district municipality, the PIT share increased from $76 \%$ to $90 \%$ from the year 2014 to 2018, which meant the increase by 14 percentage points. The data presented reveal that the PIT share differed from rural municipality to rural municipality, but competition for the tax is a slowly acting instrument. Considering the reducing number of the residents with the declared place of residence at the municipalities and this reflects the long-term trends of the lack of sustainable development, it is obvious that the situation is not a sufficient motivator for the municipality administrations to seek a specific breakthrough in attraction of investments.

The central authorities of Lithuania apply the inter-budgetary reallocation of funds and seem to follow the principles laid down in the National Strategy for Sustainable Development $(2003,2009)$ and the European Charter of Local SelfGovernance (1999), providing for implementation of financial equalization measures to ensure security for financial weaker local authority bodies, thus adjusting the unequal distribution of potential financial resources between the municipalities with the ultimate goal of eliminating the territorial, social and economic differences. The percentage share of the PIT allocated to the municipal budgets is different and reviewed on an annual basis (Fig. 4).

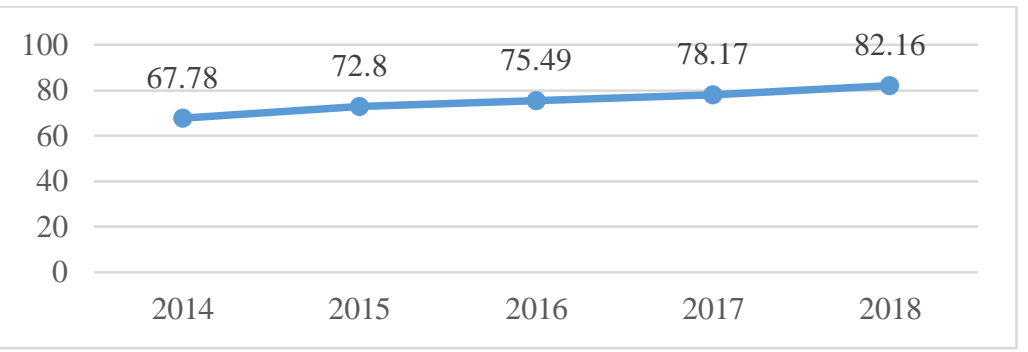

Source: Compiled by authors based on data from the Ministry of Finance of the Republic of Lithuania.

Figure 4. Personal Income Tax share, allocated to municipalities' budgets 2014-2018, percentage.

Figure 4 shows that, in 2018, $82.16 \%$ of the PIT revenues into the consolidated state and municipal budgets were allocated to the municipal budgets for implementation of their autonomous functions, of which $78.45 \%$ were the fixed share, and $3.71 \%$ - the variable share. According to the draft law, the fixed PIT share (\%) established for the year 2018 was the same as the fixed share confirmed for the year 2017 (78.17\%) and increased by EUR 5.1 mil in light of the decisions which would result in changes in the municipal budget revenues. The variable PIT share (\%) is allocated for two purposes: to increase the financial resources of municipalities and to compensate for the changes in the expenditure of municipalities due to the decisions made by the Seimas and Government.

For the first purpose, the municipalities, where the PIT per capita is lower than the national average even after the transfer of the share established under the Annex to the Law on Methodology of Determination of Municipal Budget Revenue, are supported. The legal acts of the Republic of Lithuania do not establish any specific and reasonable criteria for determination and amendment of the PIT shares received by the municipalities, and this issue causes not only the legal issue, but also the issue of social inequality. This, in turn, also determines the lack of possibilities for formation and improvement of financial autonomy in municipalities. With the view towards the second purpose, the funds necessary for elimination of the differences in the expenditure structures of municipalities which are allocated to the municipality in view of its share of the total demographic, social and other indicators of municipalities which influence objective changes in the differences of 
expenditure structures in municipalities, and the importance of the indicators. For example, in calculation of the funds subject to reallocation, the span of local roads and streets in the municipality, area of the municipality, the retired population, number of children of a certain age, built-up area in the municipality, etc. are considered. Table 2 presents the donor municipalities and PIT shares (\%) of their budgets.

Table 2. Donor municipalities and their share of the Personal Income Tax in their budgets in 2002-2018, percentage.

\begin{tabular}{|l|c|c|c|c|c|c|c|c|}
\hline \multicolumn{1}{|c|}{ Municipality } & $\mathbf{2 0 0 2}$ & $\mathbf{2 0 0 3}$ & $\mathbf{2 0 0 6}$ & $\mathbf{2 0 1 0}$ & $\mathbf{2 0 1 3}$ & $\mathbf{2 0 1 4}$ & $\mathbf{2 0 1 6}$ & $\mathbf{2 0 1 8}$ \\
\hline Vilnius city & 40 & 40 & 40 & 40 & 42 & 48 & 46 & 54 \\
\hline Kaunas city & 74 & 74 & 74 & 94 & 94 & 94 & 77 & 77 \\
\hline Klaipèda city & 64 & 64 & 64 & 86 & 86 & 86 & 87 & 87 \\
\hline Šiauliai city & 96 & 96 & 96 & 100 & 100 & 100 & 100 & 100 \\
\hline Panevėžys city & 84 & 84 & 84 & 100 & 100 & 100 & 100 & 100 \\
\hline Mažeikiai district & $\mathbf{5 5}$ & $\mathbf{5 5}$ & $\mathbf{9 0}$ & $\mathbf{9 5}$ & $\mathbf{9 9}$ & $\mathbf{1 0 0}$ & $\mathbf{1 0 0}$ & $\mathbf{1 0 0}$ \\
\hline Ignalina district & $\mathbf{7 8}$ & $\mathbf{1 0 0}$ & $\mathbf{1 0 0}$ & $\mathbf{1 0 0}$ & $\mathbf{1 0 0}$ & $\mathbf{1 0 0}$ & $\mathbf{1 0 0}$ & $\mathbf{1 0 0}$ \\
\hline Neringa city & 70 & 70 & 100 & 100 & 100 & 100 & 59 & 96 \\
\hline Other rural municipalities & $\mathbf{1 0 0}$ & $\mathbf{1 0 0}$ & $\mathbf{1 0 0}$ & $\mathbf{1 0 0}$ & $\mathbf{1 0 0}$ & $\mathbf{1 0 0}$ & $\mathbf{1 0 0}$ & $\mathbf{1 0 0}$ \\
\hline
\end{tabular}

Source: Compiled by authors based on the Law on Methodology for Determining Municipal Budgets Revenue (1997), data of the Ministry of Finance of the Republic of Lithuania and Lithuanian Free Market Institute.

Analysis of the table data has shown that, in 2002, there were eight municipalities (Vilnius city, Kaunas city, Klaipeda city, Neringa city, Panevėžys city, Šiauliai city, Ignalina and Mažeikiai districts), where the PIT share collected was transferred into the State treasury account for elimination of financial inequalities between the municipalities, while since 2014, only three donor municipalities remained, namely, Vilnius city, Kaunas city and Klaipeda city. Since 2016, another donor - Neringa municipality - extended the list of donor municipalities, and all the remaining municipalities, including the rural ones - are $100 \%$ recipients of the PIT. When comparing the PIT share in per cent allocated to the municipality budgets, it can be noticed that, in the majority of municipalities (including the rural municipalities analyzed in the article), the PIT share remained the same (100\%) from the year 2002 to 2014, while for Mažeikiai district municipality, it increased by 45 percentage points, Ignalina district municipality - 22 percentage points in the period analyzed.

Nonetheless, the existing inter-budgetary fund reallocation mechanism applied in Lithuania provides little encouragement for the regional municipalities to explore the autonomous ways of improvement of own economic, financial and social situation. The criteria followed when taking a certain share of the PIT from certain municipalities and allocating the full PIT to other municipalities also remain unclear. It is therefore obvious that the existing reallocation of interbudgetary funds is disproportionate, distorted and unsustainable, as the revenue and expenditure are not equalized between the municipalities. This information supports the problematics of financial autonomy in municipalities.

\section{CONCLUSIONS AND RECOMMENDATIONS}

The theoretical grounds of financial autonomy in municipalities are formed of the concepts of fiscal decentralization, which provide for the components of financial autonomy: resource allocation, reallocation and stabilization, allocation of revenue and expenditure, the links of intergovernmental financial transfers, borrowing mechanisms to financial autonomy in municipalities and its assessment.

Based on the empirical studies, the issues of financial autonomy in municipalities related to the lack of clarity of the legal base, assessment of the level of their economic and social condition, development inconsistencies, lack of active positions of the municipalities, irrationality and unbiasedness of inter-budgetary allocation, have been identified.

To summarize the situation of financial autonomy in rural municipalities of Lithuania, it could be claimed that the rural municipalities are very dependent on the PIT revenue received by reallocation, which limits their financial autonomy. A fairly large share of funds in rural municipalities is reallocated in a centralized manner, suggesting the assumption that the municipalities, which receive a fairly large share of revenue by inter-budgetary reallocation of funds, are more likely to be less motivated to explore other ways of drawing revenue, increasing the PIT collection volumes in their respective territories, or implementing the solutions which would help improve the economic, financial, and social situation of the respective municipality.

To improve financial autonomy in rural municipalities, actions which would enable the municipalities to attract investments, improve the business environment and policy of allocation of local taxes, optimize the operations of the municipality administration and municipal enterprises, use (lease or privatize) unused property, land, local bio-resources in a more efficient manner, reduce unreasonable expenditure of the municipality, improve the social environment by creating new jobs, reducing the unemployment rates, number of the social support recipients, etc. is needed. Nonetheless, further comprehensive investigation is necessary to support the assumptions and recommendations.

\section{REFERENCES}

1. Aristovnik A. 2012. Fiscal decentralization in Eastern Europe: a twenty-year perspective. Available at https://mpra.ub.unimuenchen.de/39316/1/MPRA_paper_39316.pdf (accessed on 20/08/2019)

2. Astrauskas A. 2002. Vietos savivalda ir vietos savivaldos problemos Lietuvoje. Viešoji politika ir administravimas, No. 3, pp. 71-78. [In Lithuanian] 
3. Astrauskas A. 2007. Decentralizacija vietos savivaldybejje: turinys ir forma. Viešoji politika ir administravimas No. 20, pp. 9-23. [In Lithuanian]

4. Astrauskas A., Striškaitė J. 2003. Lietuvos savivaldybių finansinio savarankiškumo problemos ir perspektyvos. Ekonomika No. 62, pp. 7-20. [In Lithuanian]

5. Baltušnikienė J. 2004. Fiskalinès decentralizacijos teoriniai ir metodologiniai aspektai. Pinigu studijos No.1, pp. 89-102. [In Lithuanian]

6. Baltušnikienè J. 2009. Viešojo valdymo sistemos decentralizacija: turinys, pranašumai ir trūkumai. Viešoji politika ir administravimas No. 27, pp. 79-89. [In Lithuanian]

7. Beer-Tóth K. 2009. Local financial autonomy in theory and practice. Doctoral dissertation, Faculty of Economics and Social Sciences, Université de Fribourg.

8. Bivainis J., Butkevičius A. 2003. Tarpbiudžetinis lèšų perskirstymas. Pinigų studijos No.3, pp. 35-49. [In Lithuanian]

9. Boex, J. 2001. An Introductory Overview of Intergovernmental Fiscal Relations. Georgia State University, Fiscal Policy Resource Center.

10. Buškevičiūtè E. 2008. Viešieji finansai. Kaunas, Technologija. [In Lithuanian]

11. Cigu E. 2014. An aproach of local financial autonomy and implication over sustainable development in the knowledge society. Journal of Public Administration, Finance and Law No.06, pp. 44-53.

12. Civinskas R., Tolvaišis L. 2006. Tarpbiudžetinis lèšų perskirstymas Lietuvoje: instituciniai interesai ir savivaldybių finansinis savarankiškumas. Viešoji politika ir administravimas No. 16, pp. 87-99. [In Lithuanian]

13. Davulis G. 2004. Lietuvos savivaldybių finansų analizè fiskalinès decentralizacijos požiūriu. Ekonomika ir vadyba: aktualijos ir perspektyvos No.4, pp. 69-78. [In Lithuanian]

14. Davulis G. 2006. Vietinių mokesčiu koncepcija Lietuvoje. Viešoji politika ir administravimas No. 15, pp. 19-26. [In Lithuanian]

15. Davulis G. 2007. Local Taxes in Lithuania in the Context of Integration into the European Union. Socialiniai tyrimai No. 9, pp. $62-65$.

16. Davulis, G., 2006. Lietuvos savivaldybių finansai: struktūra, raida, perspektyvos. Lietuvos statistikos darbai No.45, pp. 32-40. [In Lithuanian]

17. Davulis G., Peleckis K., Slavinskaitė N. 2013. Development of local municipality taxes and principles of fiscal policy in Lithuania. American International Journal of Contemporary Research, No. 8. pp. 38-50. [In Lithuanian]

18. Europos vietos savivaldos chartija. 1999. Teisès aktų registras. Available at https://www.etar.lt/portal/lt/legalAct/TAR.7EB8808F6CBC (accessed on 20/08/2019) [In Lithuanian]

19. Fiechter J. 2010. Politische Gemeinden und lokale Autonomie in der Schweiz. Eine Studie zur normativen Bedeutung und empirische Erfassung der Gemeindeautonomie und ihrer Auspraegung im kantonalen und lokalen Vergleich, Vol. 251. Available at https://core.ac.uk/download/pdf/77148411.pdf (accessed on 22/08/2019)

20. Friedrich P., Gwiazda J,. Nam Ch. W. 2003. Development of local public finance in Europe. Cesifo working paper No. 1107 category 1: Public finance December 2003. Available at https://papers.ssrn.com/sol3/papers.cfm?abstract_id=486065 (accessed on 20/08/2019)

21. Friedrich P., Kaltschütz A, Nam Ch. W. 2004. Recent Development of Municipal Finance in Selected European Countries. Available at https://www.econstor.eu/bitstream/10419/117090/1/ERSA2004_288.pdf (accessed on 20/08/2019)

22. Friedrich, P., Nam Ch. W., Reiljan J. 2010. Local Fiscal Equalization in Estonia: Is a Reform Necessary? In Review of Urban \& Regional Dvelopment Studies: Journal of the Applied Regional Science Conference, Vol. 22, No. 2-3, pp. 165-180. https://doi.org/10.1111/j.1467-940X.2010.00173.x

23. Jemna D.V., Onofrei M., Cigu E. 2013. Demographic and Socio-Economic Determinants of Local Financial Autonomy in Romania. Transylvanian Review of Administrative Sciences, No.9(39), pp. 46-65.

24. Kopańska A. 2017. Local governments' revenue and expenditure autonomy as a determinant of local public spending on culture. An analysis for Polish rural municipalities. European Journal of Multidisciplinary Studies, No.5(1), pp. $222-233$. https://doi.org/10.26417/ejms.v5i1.p222-233

25. Lazdynas R. 2001. Valstybè, apskritis, savivaldybè. Savivaldybių žinios No. 26(148):, pp. 12-13._[In Lithuanian]

26. Lietuvos laisvosios rinkos institutas. Available at https://www.llri.lt/naujienos/ekonomine-politika/faktai-ir-analizetarpbiudzetinis-gyventoju-pajamu-mokescio-perskirstymas/lrinka (accessed on 20/08/2019) [In Lithuanian]

27. Lietuvos Respublikos biudžeto sandaros įstatymas. 1990. Suvestinès redakcija nuo 2017-01-01. Teisès aktų registras. Available at https://www.e-tar.lt/portal/lt/legalAct/TAR.712BBBFA3D41 (accessed on 28/08/2019) [In Lithuanian]

28. Lietuvos Respublikos Finansų ministerija. Available at http://finmin.lrv.lt/ (accessed on 20/08/2019) [In Lithuanian]

29. Lietuvos Respublikos savivaldybių biudžetų pajamų nustatymo metodikos įstatymas. 1997. Suvestinès redakcija nuo 2016-12-24. Teisès aktu registras. Available at https://www.e-tar.lt/portal/lt/legalAct/TAR.F960F4CF3005 (accessed on 28/08/2019) [In Lithuanian]

30. Lietuvos Respublikos Statistikos departamentas. Available at https://osp.stat.gov.lt/statistiniu-rodikliu-analize\#/ (accessed on 20/08/2019) [In Lithuanian] 
31. Lietuvos Respublikos valstybės biudžeto ir savivaldybių biudžetų sudarymo ir vykdymo tvarka. 2001. Suvestinės redakcija nuo 2016-01-01. Teisès aktų registras. Available at https://www.e-tar.lt/portal/lt/legalAct/TAR.55AE7A4E7975 (accessed on 28/08/2019) [In Lithuanian]

32. Lietuvos Respublikos vietos savivaldos ịstatymas. 1994. Suvestinès redakcija nuo 2017-01-01-2017-12-31. Teisès aktų registras. Available at https://www.e-tar.lt/portal/lt/legalAct/TAR.D0CD0966D67F (accessed on 28/08/2019) [In Lithuanian]

33. Mačiulytė, J. Ragauskas, P. 2007. Lietuvos savivalda: savarankiškos visuomenès link? Vilnius: Versus aureus._[In Lithuanian]

34. Mclure C., Martinez-Vazquez J. 2000. The Assignment of Revenues and Expenditures in Intergovernmental Fiscal Relations. World Bank Institute. Available at http://www1.worldbank.org/publicsector/decentralization/March2004Course/AssignmentRevenues.pdf (accessed on 22/08/2019)

35. Mosteanu,T., Lacatus C. M. 2008. The Municipal Bonds-the Cause and the Effect of the Local Financial Decentralisation Growth. Romanian Case. Theoretical and Applied Economics, No.9(9), pp. 51-60.

36. Musgrave R. A. 1959. The Theory of Public Finance. A Study in Public Economy. New York: McGraw Hill.

37. Oates W. E. 1999. An Essay on Fiscal Federalism. Journal of Economic Literature, No.37(3): pp. 1120-1149. https://doi.org/10.1257/jel.37.3.1120

38. Oulasvirta L., Turała M. 2005. Measuring the financial autonomy of local governments with a local autonomy index. Caledonian Business School, Glasgow Caledonian Aniversity. Available at https://www.econstor.eu/bitstream/10419/117090/1/ERSA2004_288.pdf (accessed on 22/08/2019)

39. Oulasvirta L., Turala M. 2009. Financial autonomy and consistency of central government policy towards local governments. International Review of Administrative Sciences No.75(2), pp. 311-332. https://doi.org/10.1177/0020852309104178

40. Psycharis Y., Zoi M. and Iliopoulou, S. 2016. Decentralization and local government fiscal autonomy: evidence from the Greek municipalities. Environment and Planning C: Government and Policy, No.34(2), pp. $262-280$. https://doi.org/10.1177/0263774X15614153

41. Raipa A., Backūnaitė E. 2004. Decentralizacijos reformų teoriniai ir taikomieji aspektai. Viešoji politika ir administravimas No. 7, pp. 23-32. [In Lithuanian]

42. Rudytė D., Ruplienė D., Garšvienè L., Bajorūnienė R., Skunčikienė S. 2018. Savivaldybių fiskalinio konkurencingumo vertinimas ekonominio augimo kontekste. Mokslo studija. Available at_http://gs.elaba.lt/object/elaba:27762649/(accessed on 30/08/2019) [In Lithuanian]

43. Santos S. P. M. A. 2016. State reform, decentralization and financial autonomy of local government. Rio de Janeiro State University.

44. Scutariu A.L., Scutariu P. 2015. The link between financial autonomy and local development. The case of Romania. Procedia Economics and Finance, No.32, pp. 542-549. https://doi.org/10.1016/S2212-5671(15)01430-6

45. Slavinskaitė N. 2017. Šalies fiskalinès decentralizacijos vertinimas. Doctoral dissertation, Vilnius Gediminas Technical University. [In Lithuanian] https://doi.org/10.20334/2017-025-M

46. Tiebout, Ch. 1956. A Pure Theory of Local Expenditures. Journal of Political Economy No.64(5), pp. 416-424. https://doi.org/10.1086/257839

47. Vidickienè D., Melnikienè R. 2008. Lietuvos kaimiškujų regionų kaip gyvenamosios vietos patrauklumo vertinimas. Žemés ūkio mokslai, No. 1, pp. 51-59. [In Lithuanian]

48. Vidickienė D., Melnikienė R. 2008. Paramos teikimo Lietuvos kaimo regionams kriterijų vertinimas. Vadybos mokslas ir studijos - kaimo verslu ir ju infrastruktūros plètrai/Management theory and studies for rural business and infrastructure development, No.12(1), pp.168-174. [In Lithuanian]

49. Wei L. I. 2014. Financial Autonomy, Local Government Expenditure Preference and Its Behavior Choice. Modern Finance and Economics. http://en.cnki.com.cn/Article_en/CJFDTotal-XCXB201409004.htm

50. Zafra-Gómez J.L., Pedauga L.E., Plata-Díaz A.M., López-Hernández A.M. 2014. Do local authorities use NPM delivery forms to overcome problems of fiscal stress? Spanish Journal of Finance and Accounting/Revista Espanola de Financiacion $y$ Contabilidad, No.43(1), pp. 21-46. https://doi.org/10.1080/02102412.2014.890823 